\title{
Adult Fanconi syndrome progressing to multiple myeloma
}

\author{
RL SEWELL, ${ }^{*}$ MS DORREEN \\ From the Imperial Cancer Research Fund Department of Medical Oncology, St Bartholomew's Hospital, \\ London EC1A $7 B E$
}

SUMMARY A case of adult Fanconi syndrome is described in which there was urinary excretion of $\kappa$ light chains. After 13 years the patient developed overt myeloma. She also developed an adenocarcinoma of the colon and an adenocarcinoma of the parathyroid gland. These findings are discussed in relation to the known association between adult Fanconi syndrome, renal damage, and myeloma.

Adult Fanconi syndrome consists of a group of abnormalities resulting from dysfunction of the proximal renal tubules. These include glycosuria, phosphaturia, aminoaciduria, acidosis, and often osteomalacia. ${ }^{2}$ Twenty patients have been described in the published work ${ }^{1-8}$ with adult Fanconi syndrome and Bence Jones proteinuria, due to $\kappa$ light chains in all cases typed. These patients fall into two groups: in 13 patients adult Fanconi syndrome preceded the development of myeloma or amyloidosis often by many years, whereas in seven patients the syndrome and myeloma were diagnosed simultaneously. It has been suggested that patients with adult Fanconi syndrome and Bence Jones proteinuria who develop myeloma or amyloidosis constitute a distinct type of monoclonal gammopathy. ${ }^{2}$

The case reported here had a history which terminated in myeloma after 13 years. In addition, she developed two adenocarcinomas: that of the colon was removed surgically while that of the parathyroid gland was discovered at necropsy.

\section{Case report}

A 53 year old white woman presented in August 1967 with a six week history of bone pain. There were no abnormal physical signs, although she had had some difficulty in walking for 10 months. Results of biochemical and radiological examinations are shown in the Table. Adult Fanconi syndrome was diagnosed on the basis of persistent

\footnotetext{
*Present address: Imperial Cancer Research Fund, Lincoln's Inn Fields, London WC2A 3PX.
}

Accepted for publication 8 August 1984 glycosuria, phosphaturia, amnioaciduria, and acidosis. Proteinuria was noted. There was no radiological evidence of osteomalacia, but the low serum phosphate and raised alkaline phosphatase values were suggestive of bone disease. A blood count was normal. As the symptoms were mild we decided initially to observe the patient's progress. In 1968 treatment with vitamin D $2500 \mathrm{U}$ daily and Shohl's solution $15 \mathrm{ml}$ three times daily was started. In 1970 generalised loss of bone density from the hands was noted. She continued on vitamin D and Shohl's solution.

In 1974 the proteinuria was reinvestigated and shown to be due to the presence of $\kappa$ light chains. In February 1975 serum immunoglobulin concentrations were: $\operatorname{IgG} 9.7 \mathrm{~g} / \mathrm{l}$, IgA $0.65 \mathrm{~g} / \mathrm{l}$, and $\operatorname{IgM} 0.6 \mathrm{~g}$. These values decreased and in October 1979 reached: $\operatorname{IgG~} 5 \cdot 1 \mathrm{~g} / \mathrm{l}, \operatorname{IgA} 0.4 \mathrm{~g} / 1$, and IgM $0.3 \mathrm{~g} / \mathrm{l}$. In September 1975 her absolute lymphocyte count was at the lower limit of normal; lymphocyte morphology, response to Bordetella pertussis in vitro, and periodic acid Schiff score were all normal. In 1975 and again in 1977 bone marrow examination failed to show an increase in plasma cells but in both bone marrow samples there were occasional atypical plasma cells containing crystalline inclusions.

In November 1977 two benign rectal polyps were removed. In December 1977 she became symptomatically hypercalcaemic (calcium concentration $3.25 \mathrm{mmol} / \mathrm{l}$ ) with nausea, vomiting, and anorexia. Serum alkaline phosphatase was $55 \mathrm{IU} / \mathrm{l}$. The hypercalcaemia was thought to be due to treatment with vitamin $\mathrm{D}$, which was stopped. A low calcium diet was started, and after this she felt much better. In July 1978 she complained of generalised weariness, bone pains, and difficulty in moving her lower 
Results of biochemical investigations of serum and urine at diagnosis of Fanconi syndrome

\begin{tabular}{|c|c|c|}
\hline Investigation & Serum & Urine \\
\hline $\begin{array}{l}\text { Calcium } \\
\text { Creatinine } \\
\text { Creatinine clearance } \\
\text { Phosphate } \\
\text { Protein } \\
\text { Glucose } \\
\text { Urea } \\
\text { Uric acid } \\
\text { Sodium } \\
\text { Potassium } \\
\text { Chloride } \\
\text { Bicarbonate } \\
\text { Alkaline phosphatase } \\
\text { pH } \\
\text { Amino acids }\end{array}$ & $\begin{array}{l}2.5 \mathrm{mmol} / \mathrm{l}(2 \cdot 20-2 \cdot 60) \\
120 \mathrm{mmol} / \mathrm{l}(62-115) \\
0 \cdot 7 \mathrm{mmol} / \mathrm{l}(0 \cdot 8-1 \cdot 5) \\
68 \mathrm{~g} / \mathrm{l}(62-80) \\
\text { Normal clearance } \\
6 \cdot 5 \mathrm{mmol} / \mathrm{l}(2 \cdot 5-6 \cdot 6) \\
0 \cdot 19 \mathrm{mmol} / 1(0 \cdot 12-0 \cdot 42) \\
138 \mathrm{mmol} / 1(135-146) \\
4 \cdot 0 \mathrm{mmol} / 1(3 \cdot 5-5 \cdot 0) \\
108 \mathrm{mmol} / 1(95-105) \\
17 \mathrm{mmol} / 1(22-30) \\
280 \mathrm{IU} / \mathrm{l}(30-130) \\
-\end{array}$ & $\begin{array}{l}100 \mathrm{mmol} / \text { day }(7 \cdot 0) \\
795 \mathrm{mmol} / \mathrm{day}(9-18) \\
45 \mathrm{ml} \text { plasma/min } \\
358 \mathrm{mmol} / \mathrm{day}(15-50) \\
2 \cdot 3 \mathrm{~g} / \mathrm{day} \\
++\end{array}$ \\
\hline
\end{tabular}

Values in parentheses $=$ normal range

limbs and reported having a few falls. In September 1978 she broke her wrist while getting into a swimming pool. In January 1979 she complained of weakness in the legs and difficulty in getting out of chairs. The serum alkaline phosphatase value was $149 \mathrm{IU} / 1$ and electrophoresis showed bone type enzyme. Treatment with dihydrotachysterol $0.2 \mathrm{mg}$ on alternate days was started. In April 1980 she was hypothyroid and treatment with thyroxine $0.05 \mathrm{mg}$ daily was started. From April 1979 the haemoglobin concentration had been falling slowly, and in May 1980 it reached $8.8 \mathrm{~g} / \mathrm{dl}$, with a mean cell haemoglobin of $31 \mathrm{pg}$. At this time a bone marrow examination showed a patchy increase in plasma cells of up to $25 \%$, the appearances being compatible with a diagnosis of myeloma. Most of the plasma cells contained crystalline inclusions. Treatment was started with cyclophosphamide $250 \mathrm{mg}$ daily in three day courses at four weekly intervals.

In June 1980 a further two benign rectal polyps were removed. In July 1980 colonoscopy showed a lesion of the ascending colon. At this time she was weak and anaemic and felt nauseated almost continuously with occasional vomiting. There were areas of abdominal tenderness and she had occasional sharp abdominal pains. In August 1980 a right hemicolectomy was performed. Histology showed a well differentiated adenocarcinoma of the colon. Regional lymph nodes showed no metastatic tumour. Two benign polyps were also removed.

In October 1980 she was suffering from anaemia and required occasional blood tranfusions. In early February 1981 she was again anaemic and unwell and was transfused. Subsequently, she had several episodes of epistaxis and her condition deteriorated. She developed pulmonary oedema and bronchopneumonia and died on 23 February.
A postmortem examination was carried out two days later. The kidneys were both small, weighing $105 \mathrm{~g}$, and showed pronounced thinning of the cortex. Histology showed tubular protein casts but the tubular epithelium was autolysed. The spleen weighed $570 \mathrm{~g}$ and was infiltrated with plasma cells. Bone marrow showed destruction of cancellous bone and diffuse infiltration with plasma cells containing rhomboid inclusions. The plasma cells constituted half of the cellular elements. The appearances and histology of the lungs confirmed bronchopneumonia. A papilliary adenocarcinoma of the parathyroid gland was found. There was no evidence of amyloidosis in any of the organs examined.

\section{Discussion}

The case reported here showed the classic symptoms and laboratory findings of adult Fanconi syndrome. Throughout her 13 year history there was proteinuria, which was due to $\kappa$ light chains. All 11 cases who have had their urinary protein typed have had $\kappa$ light chains. ${ }^{2-5}$ In the two bone marrow samples taken in 1975 and 1977 the atypical plasma cells contained crystalline inclusions similar to those described in nine cases in the published work. ${ }^{24}$ In our patient the serum calcium concentration was normal, which is in agreement with other reported cases and in contrast to many patients with myeloma. Biochemical evidence of osteomalacia developed in our patient but there was no radiological evidence in the early stages. The wrist fracture was associated with her generalised bone disease.

Serum immunoglobulin concentrations were first measured eight years after adult Fanconi syndrome was diagnosed. The steady decline from the lower limit of the normal range over five years to frankly 
low levels of $\operatorname{IgG}, \operatorname{IgA}$, and $\operatorname{IgM}$ reflected the transition to overt myeloma. Immunoglobulin concentrations have been reported in six cases in the published work. Values were generally at or below the lower limit of normal for IgG, IgA, and IgM. In one case the IgG was near the lower limit of normal, the IgA was normal, but the IgM was low. Another patient had a normal IgG value but 18 months later this was low; the $\operatorname{IgA}$ and $\operatorname{IgM}$ values were always low. A further patient had a normal IgG value but the IgA and IgM values were just below the lower limit of normal..$^{24-8}$ Our patient's absolute lymphocyte count declined and in 1979 she was frankly lymphopenic, but her in vitro response to $B$ pertussis was normal. In untreated myeloma one third of patients are lymphopenic but most fail to respond to $B$ pertussis in vitro.

Our patient was unusual in that she developed a well differentiated adenocarcinoma of the colon shortly after myeloma was diagnosed. The existence of a papilliary adenocarcinoma of the parathyroid gland was an unexpected finding at necropsy. The time interval is clearly too short for chemotherapy to be implicated as a causative factor in the carcinoma of the colon or thyroid. Whether her depressed immune state is relevant is a matter of conjecture. None of the other 20 cases in the published work had a second malignancy and many of these patients had histories of 5-12 years.

With regard to the underlying disease in this group of patients, the presence and excretion of $\kappa$ light chains clearly indicates a basic plasma cell disorder. In reviewing the published work it becomes clear that in seven cases myeloma and adult Fanconi syndrome were diagnosed simultaneously. ${ }^{\text {s }}$ There was, however, a history of glycosuria or proteinuria or both in most instances of one to three years duration. In 13 cases adult Fanconi syndrome and proteinuria preceded the development of myeloma or amyloidosis, often by many years. ${ }^{1-4678}$ Neither had supervened in three cases at the time of reporting and there was one case of sudden death of unknown cause. It has been suggested that light chains, which are catabolised in the proximal tubules of the kidney, are toxic to the tubular cells and that the development of adult Fanconi syndrome is secondary to renal tubular damage..$^{2510}$ The finding of crystalline inclusions in the plasma cells of nine cases $^{24}$ and in our case and similar inclusions in the renal tubular cells of eight cases ${ }^{24}$ adds weight to these arguments. Renal damage by light chains and subsequent tubular defects are variable $e^{261011}$ and it is not yet clear whether these differences are due to altered amino acid sequences of the light chains in individual cases. ${ }^{12}$ There have been no reports of Fanconi syndrome developing after myeloma.

Adult Fanconi syndrome with excretion of $\kappa$ light chains has become established as a distinct type of monoclonal gammopathy with slow progression to overt myeloma or amyloidosis in two thirds of cases. Patients with unexplained disorders of renal tubular function should be carefully investigated for light chain proteinuria and evidence of osteomalacia.

We thank Professor JS Malpas and Dr WR Cattell for their advice.

\section{References}

' Harrison JF, Blainey JD. Adult Fanconi syndrome with monoclonal abnormality of immunoglobulin light chains. $J$ Clin Pathol 1967; 20:42-8.

${ }^{2}$ Maldonado JE, Velosa JA, Kyle RA, Wagoner RD, Holley KE, Salassa RM. Fanconi syndrome in adults: a manifestation of a latent form of myeloma. Am J Med 1975;58:354-64.

${ }^{3}$ Alcalay M, Liere C, Bontoux D, Babin P, Frocrain C. $\kappa$ chain disease and Fanconi syndrome of the adult. Nouv Presse Med 1975; 4:974-6.

${ }^{4}$ Hirai H, Shida M, Igei I, et al. A case of Bence Jones $\kappa$ myeloma with adult Fanconi syndrome. Rinsho Ketsueki 1978;19:2349.

${ }^{5}$ Gailani S, Seon BK, Henderson ES. $\kappa$ light chain-myeloma associated with adult Fanconi syndrome: response of the nephropathy to treatment of myeloma. Med Pediatr Oncol 1978;4:141-7.

- Horn ME, Knapp MS, Page FT, Walker WHC. Adult Fanconi syndrome and multiple myeloma. J Clin Pathol 1969;22:414-6.

${ }^{7}$ Lee DBN, Drinkard JP, Rosen VJ, Gonick HC. The adult Fanconi syndrome. Medicine 1972;51:107-38.

${ }^{8}$ Finkel PN, Kronenberg K, Pesce AJ, Pollak VE, Pirani CL. Adult Fanconi syndrome, amyloidosis and marked $\kappa$ light chain proteinuria. Nephron 1973;10:1-24.

${ }^{9}$ Sewell RL. Lymphocyte abnormalities in myeloma. $\mathrm{Br} \mathrm{J}$ Haematol 1977;36:545-51.

${ }^{10}$ Fudenbeg HH, Virella G. Multiple myeloma and Waldenstrom macroglobulinemia: unusual presentations. Semin Hematol 1980; 17:63-79.

" Kyle RA, Greipp PR. "Idiopathic" Bence Jones proteinuria. $N$ Engl J Med 1982;306:564-7.

${ }^{12}$ Seon BK. Unique amino acid sequence of Bence Jones proteins in the urine of patients with adult Fanconi syndrome. Mol Immunol 1982; 19:83-6.

Requests for reprints to: Dr RL Sewell, Imperial Cancer Research Fund, Lincoln's Inn Fields, London WC2A 3PX, England. 